\title{
Quantification of oestrogen receptors in breast cancer: radiochemical assay on cytosols and cryostat sections compared with semiquantitative immunocytochemical analysis
}

\author{
H M E SCHERES, A F P M DE GOEIJ, M J M ROUSCH, G G HONDIUS, \\ D D WILLEBRAND, A H GIJZEN, * F T BOSMAN
}

\section{From the Department of Pathology, University of Limburg, Maastricht, The Netherlands, and the *De Wever Hospital, Heerlen, The Netherlands}

SUMMARY A radiochemical oestrogen receptor assay on cytosol was correlated with a radiochemical and an immunohistochemical oestrogen receptor assay using cryostat sections from 50 breast cancer specimens. Oestrogen receptors were reliably quantitated in $6 \mu \mathrm{m}$ cryostat sections with Scatchard analysis using radiolabelled oestradiol, and a good quantitative and qualitative relation with cytosol oestrogen receptor assay was found. Parallel sections were used for routine histological tissue verification and for direct comparison with immunohistochemistry for oestrogen receptor. Specific immunoperoxidase staining with a rat monoclonal antibody was scored by semiquantitative evaluation of the staining intensity of cancer cell nuclei. Oestrogen receptor scoring was highly reproducible when performed by the same observer. The semiquantitative immunohistochemical oestrogen receptor score correlated significantly better with the radiochemical assay on sections than with cytosol assay.

Oestrogen receptor in breast cancer can be reliably assayed by semiquantitative evaluation of cryostat sections immunostained for oestrogen receptor, but only if the procedure is adequately standardised. The results underline the importance of cellular heterogeneity as a cause of variation in oestrogen receptor assay evaluation in breast cancer.

Oestrogen receptor assays on cytosol preparations from malignant tissue are valuable for prognosis and for selecting patients with breast cancer for endocrine treatment..$^{1-3}$ Steroid receptors are routinely measured with radiolabelled ligands through their specific binding function. Enzyme immunoassays using monoclonal antibodies that recognise determinants on the receptor protein have also recently been applied to assess oestrogen receptor concentrations in cytosol or nuclear fractions of breast cancer biopsy specimens. ${ }^{4-6}$ Oestrogen receptor assays on cytosols, however, do not have an optimal predictive value. A positive cytosol oestrogen receptor assay does not guarantee a positive response to oestrogen therapy: only $60 \%$ of the oestrogen receptor positive patients benefit from endocrine treatment. On the other hand, prediction of response to hormone treatment is more reliable for patients with oestrogen receptor negative tumours of whom only about $10 \%$ react favourably. ${ }^{2}$ The heterogeneous nature of most breast cancer specimens

Accepted for publication 13 January 1988 is presumably one of the main factors responsible for the limited predictive value of receptor assays on homogenised tissue, and highly variable oestrogen receptor concentrations within a biopsy specimen have been found..$^{7-12}$ In many cases of oestrogen receptor analysis the tissue composition-that is, the relative amount of connective tissue, normal tissue, or necrosis of malignant tissue-is unknown. As the receptor content is expressed in $\mathrm{fmol} / \mathrm{mg}$ of protein, this may be an important source of errors. ${ }^{7} 10111314$

Assays of tissue sections could overcome some of the limitations of oestrogen receptor assays in homogenised neoplastic tissues. ${ }^{15-18}$ We developed a radiochemical oestrogen receptor assay on cryostat sections of target tissues, which permits Scatchard analysis of both soluble and section bound oestrogen receptor on relatively small samples $(50-80 \mathrm{mg}$ of tissue). ${ }^{19}$ With this technique, parallel sections can be used to verify tissue composition or to perform histochemical and immunohistochemical correlative studies.

The development of specific anti-oestrogen receptor 
monoclonal antibodies has permitted the visualisation of oestrogen receptor with immunohistochemical techniques, ${ }^{2021}$ and several published reports describe the semi-quantification of the immunohistochemical reaction. ${ }^{22-24} \mathrm{~A}$ correlative study was recently reported in which oestrogen receptor immunohistochemical analysis and a radioligand binding assay on adjacent breast cancer sections were applied, ${ }^{25}$ In a similar study we compared an oestrogen receptor assay with radiolabelled oestradiol and semi-quantitative histochemical detection with a monoclonal antibody using parallel cryostat sections of breast cancer tissue.

\section{Material and methods}

\section{TISSUE SAMPLES}

Tissue samples from 50 surgically removed primary breast carcinomas were selected and histologically typed in the surgical pathology division of our department. Immature bovine uterus was used as standard tissue for the radiochemical oestrogen receptor section assay. The tissue samples were rapidly frozen in isopentane cooled with dry ice $\left(-70^{\circ} \mathrm{C}\right)$ and stored at $-80^{\circ} \mathrm{C}$.

Each tumour block was divided into five adjacent parts. The first two parts were used for diagnostic purposes. The third and fifth part were homogenised for the preparation of cytosol; the fourth part, adjacent to the blocks for the cytosol assay, was used for the preparation of cryostat sections.

Serial $6 \mu \mathrm{m}$ frozen sections were used for radiochemical detection of oestrogen receptor and for the immunocytochemical localisation of the oestrogen receptor protein.

\section{RADIOCHEMICAL ASSAY ON CYTOSOL}

PREPARATIONS

Cytosol oestrogen receptor was measured with a multiple point dextran-coated charcoal assay according to the recommendations of the EORTC group $^{26}$ (with ${ }^{125}$ I-estradiol). These assays were performed in the laboratory of the De Wever Hospital, Heerlen (Dr A Gijzen). Both laboratories participate in a steroid receptor assay quality control programme. ${ }^{27}$

\section{RADIOCHEMICAL ASSAY ON FROZEN SECTIONS}

Frozen sections were cut at $6 \mu \mathrm{m}$ and mounted on gelatin chrome alum-coated coverslips $(40 \times 20 \mathrm{~mm})$ as reported previously by De Goeij et al. ${ }^{19}$ Several nonmounted sections were used to determine protein concentration according to the method of Bradford. ${ }^{28}$ Briefly, the mounted and dried unfixed sections were defatted by immersion in petroleum ether $\left(40^{\circ}-60^{\circ} \mathrm{C}\right)$ for five minutes, three times, and dried in air. Subsequently the sections were overlayed with 150 . $\mathrm{k}$ of buffer containing $0.01 \mathrm{M} \mathrm{K}_{2} \mathrm{HPO}_{4} / \mathrm{KH}_{2} \mathrm{PO}_{4}(\mathrm{pH} 7.5)$,
$0.0015 \mathrm{M} \mathrm{K}_{2}$ edetic acid, $0.003 \mathrm{M} \mathrm{NaN}_{3}, 0.01 \mathrm{M}$ monothioglycerol, and $10 \%$ glycerol (EORTC buffer) ${ }^{25}$ Incubation in triplicate with $4,2,1,0.5$ and $0.25 \mathrm{nM}\left[{ }^{3} \mathrm{H}\right]$-estradiol (Amersham International, UK) in the presence and absence of a 100 -fold excess of diethylstilboestrol was performed in a humid chamber overnight at $4^{\circ} \mathrm{C}$. During incubation, part of the tissue receptor content diffused into the overlaying buffer. The specific protein-bound radioactivity which eluted from the sections was determined with a dextran-coated charcoal assay and designated as "soluble" receptor. After washing the sections with EORTC buffer the binding of radiolabel to the sections was measured by direct liquid scintillation counting of the coverglass-bound sections. This determination yielded the section-bound receptor. The total tissue oestrogen receptor content in the section assay was defined as the sum of "soluble" and sectionbound oestrogen receptor and expressed as $\mathrm{fmol} / \mathrm{mg}$ of total protein.

\section{PROTEIN DETERMINATIONS}

Non-mounted sections were solubilised with $150 \mu 11$ $\mathrm{N} \mathrm{NaOH}$ at $100^{\circ} \mathrm{C}$ for 10 minutes in stoppered glass tubes. Protein content of $100 \mu \mathrm{l}$ aliquots of solubilised sections, homogenates, and cytosol samples was determined according to the method of Bradford ${ }^{28}$ using bovine serum albumin as a standard.

\section{IMMUNOSTAINING PROCEDURE ON SECTIONS}

-The immunostaining was performed using the oestrogen receptor-immunocytochemical assay kit according to the manufacturer's instructions (Abbot Laboratories, Diagnostic Division, The Netherlands), with one modification: the primary antibody was used in a dilution of $1 / 4$. Briefly, cryostat sections of $6 \mu \mathrm{m}$ were fixed in picric acid-paraformaldehyde ${ }^{29}$ for 10 minutes at $4^{\circ} \mathrm{C}$ and stored at $-20^{\circ} \mathrm{C}$ in specimen storage medium $\left(42.8 \mathrm{~g}\right.$ sucrose, $0.33 \mathrm{~g} \mathrm{MgCl}_{2}$ in 500 $\mathrm{ml}$ phosphate buffered saline (PBS) and glycerol $1 / 1$ ) for a maximum of two weeks before staining. The sections were incubated for 15 minutes with normal goat serum $(1 / 5)$ to reduce non-specific binding of the antibodies. Subsequently the sections were incubated overnight at room temperature with the rat-anti-oestrogen receptor antibody developed by Greene $e t$ a ${ }^{0}$ (H222Sp $\gamma$, diluted $1 / 4$ in $1 \%$ bovine serum albuminphosphate buffered saline) rinsed twice for five minutes in PBS, and then incubated with goat anti-rat IgG for 30 minutes, rinsed twice for five minutes in PBS and incubated 30 minutes with the peroxidaseantiperoxidase complex, rinsed in PBS and finally incubated for seven minutes in chromogen (diaminobenzidine with $0.03 \%$ hydrogen peroxide in PBS), counterstained with Harris's hematoxylin, and mounted in Entellan. As a negative control, an adjacent 
section was stained according to the same procedure but with normal rat IgG. For every staining procedure, oestrogen receptor positive cells, supplied with the Abbott kit or frozen sections of oestrogen receptor positive mammary carcinomas served as positive controls.

The intensity and distribution of the specific staining was visually evaluated using a modification of the semiquantitative analysis of McCarty et al. ${ }^{22}$ The immunohistochemical oestrogen receptor score was expressed as follows:

Oestrogen receptor score $=\sum_{i=0}^{i=4} P(i) \times i$, where $\mathrm{i}=$ intensity of staining $(0-4)$ and $\mathrm{P}(\mathrm{i})=$ percentage of stained tumour cells in category i (0-100\%).

The classification of the staining intensity was assessed on at least three separate cohorts of 100 tumour cells from each tumour of different high power $(\times 400)$ fields, which allowed heterogeneity in tumour cell receptor content to be assessed. Scoring was performed by two pairs of independent observers working without prior knowledge of the cytosol oestrogen receptor content. Before scoring of the breast cancer sample the observer pairs reached a consensus on classification by using the reference preparation included in the oestrogen receptor-ICA kit. The final oestrogen receptor score of the sample was obtained by calculating the mean of all scores.

\section{Results}

COMPARISON OF RADIOCHEMICAL DETECTION OF OESTROGEN RECEPTOR IN CYTOSOL AND FROZEN SECTIONS

The Scatchard plots of the binding of radiolabelled oestradiol to $6 \mu \mathrm{m}$ unfixed frozen sections of two oestrogen receptor positive breast cancer specimens are shown in fig 1 . This radiochemical section assay

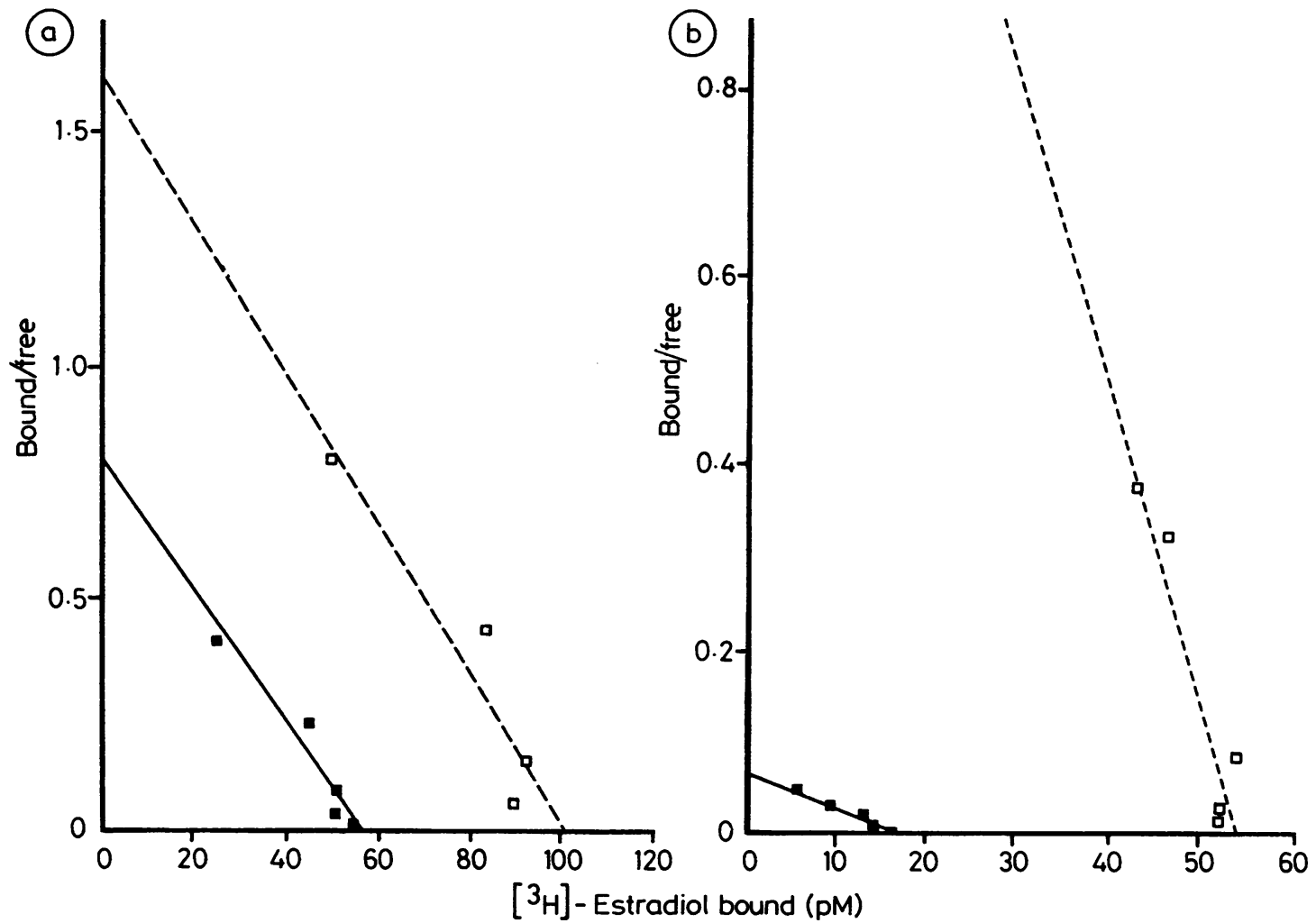

Fig 1 Scatchard analysis of radiochemical oestrogen receptor assay on cryostat sections of two human breast cancer samples $\square--\square$ : soluble oestrogen receptor; $\square-\square$ : section-bound oestrogen receptor. (a) Section-bound: Bmax $=373 \mathrm{fmol} / \mathrm{mg}$ tissue protein, $\mathrm{Kd}=0.07 \mathrm{nM}$; soluble: Bmax $=663 \mathrm{fmol} / \mathrm{mg}$ tissue protein, $\mathrm{Kd}=0.06 \mathrm{nM}$. (b) Section-bound: Bmax $=40 \mathrm{fmol} / \mathrm{mg}$ tissue protein, $K d=\theta \cdot 28 \mathrm{nM} ; \cdot$ soluble: Bmax $=122 \mathrm{fmol} / \mathrm{mg}$ tissue protein, $K d=0.03 n M$. 


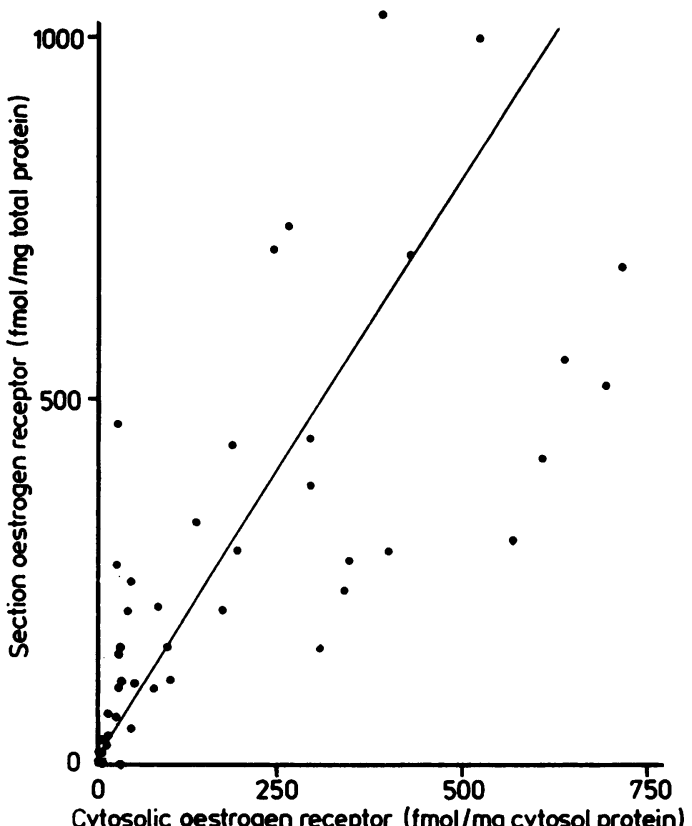

Fig 2 Comparison of radiochemical oestrogen receptor in cytosol and cryostat sections from 50 breast cancer samples. Linear regression is characterised by: $y=17 \cdot 5+1.55 x$; $r=0.70 ; p<0.00001$. Note that cytosol oestrogen receptor is expressed as fmol/mg cytosol protein and section oestrogen receptor (soluble + section-bound) as fmol/mg total tissue protein.

shows the presence of oestrogen receptors, characterised by saturable and high affinity binding of oestradiol (dissociation constant $\mathrm{kd}=0.05-1.0 \mathrm{nM}$ ). The reproducibility of this assay was determined by multiple assays $(n=9)$ on calf uterus, and the interassay variation for oestrogen receptor determination

Table 1 Correlation of radiochemical oestrogen receptor assay in cytosol and sections: classification* of receptor positive and negative breast cancer samples $(n=50)$

$\begin{aligned} & \text { Cytosol assay } \\ & \text { (fmol oestrogen receptor/ } \\ & \text { mg cytosol protein) }\end{aligned}$
$\begin{aligned} & <10 \quad \geqslant 10\end{aligned}$

Section assay

(fmol oestrogen receptor/mg tissue protein)

$<33 \quad 10(20 \%) \quad 1+(2 \%)$

$\geqslant 33 \quad 1 \ddagger(2 \%) \quad 38(76 \%)$

*For cytosol assay a cut off value of $10 \mathrm{fmol} / \mathrm{mg}$ cytosol protein was used, corresponding to $33 \mathrm{fmol} / \mathrm{mg}$ tissue protein according to equation $y=17.5+1.55 x$, experimentally determined in experiments from fig 2 . Specificity $=91 \%$; sensitivity $=97.5 \%$. tThis sample had $10 \mathrm{fmol}$ oestrogen receptor/mg of cytosol protein in the cytosol and $16 \mathrm{fmol}$ oestrogen receptor/mg tissue protein in the sections.

†This sample had no detectable oestrogen receptor/mg cytosol protein in the cytosol and $37 \mathrm{fmol} / \mathrm{mg}$ tissue protein in the sections. resulted in a coefficient of variation of $17.5 \%$.

The results of the radiochemical quantitation of oestrogen receptor sites in cytosol and cryostat sections in a series of 50 breast cancer specimens are illustrated in fig 2 . The two oestrogen receptor assays showed a significant linear correlation $(r=0.70$; $\mathrm{p}<0.00001$ ). The relative amount of soluble receptors varied from 20 to $80 \%$ of the total sample content and no significant relation was found between the number of oestrogen receptors in the cytosol and in the soluble fraction of the sections (results not shown). The mean (SEM) Kd for the cytosol oestrogen receptor assay was $0.31(0.61) \mathrm{nM}$ compared with 0.30 $(0.43) \mathrm{nM}$ for the section-bound oestrogen receptor and $0 \cdot 16(0.20) \mathrm{nM}$ for the soluble oestrogen receptor. The mean $\mathrm{Kd}$ for the section-bound and soluble oestrogen receptor differed significantly from each other according to Students's $t$ test $(p<0.01)$. These results show that the radiochemical assays on cytosol and frozen sections detect high affinity binding sites corresponding to oestrogen receptors. The $\mathrm{Kd}$ data also indicate that the oestrogen receptors eluted from the sections and detected as soluble receptors show a higher binding affinity than the receptors which remain bound to the sections.

Classification of the 50 samples into oestrogen receptor positive and negative breast cancers, as determined with both assays, is shown in table 1 . For the cytosol assay a cut off value of $10 \mathrm{fmol}$ oestrogen receptor/mg of cytosol protein was generally used. The corresponding cut off value for the section assay was $33 \mathrm{fmol}$ oestrogen receptor $/ \mathrm{mg}$ tissue protein. The agreement between both assays was excellent, with a sensitivity of $97.5 \%$ and a specificity of $91 \%$. Two cases were discordant, but receptor contents were near the borderline values (table 1).

The receptor values were expressed in a different way for the cytosol and the section assay. For obvious reasons the cytosol oestrogen receptor content was determined in $\mathrm{fmol} / \mathrm{mg}$ cytosol protein and section oestrogen receptor in $\mathrm{fmol} / \mathrm{mg}$ total tissue protein. To compare the results of both assays based on the same amount of tissue the cytosol oestrogen receptor content was also expressed per mg total tissue protein. Cytosol protein represents $48(9 \%)(n=50)$ of the total tissue protein. Recalculation of the cytosol receptor data on the basis of the amount of total tissue protein in the sample showed that about three times more oestrogen receptor was recovered from the same amount of tissue with a section assay compared with a cytosol assay.

\section{COMPARISON OF IMMUNOCYTOCHEMICAL AND RADIOCHEMICAL DETECTION OF OESTROGEN RECEPTOR} Only nuclear staining could be observed in the 


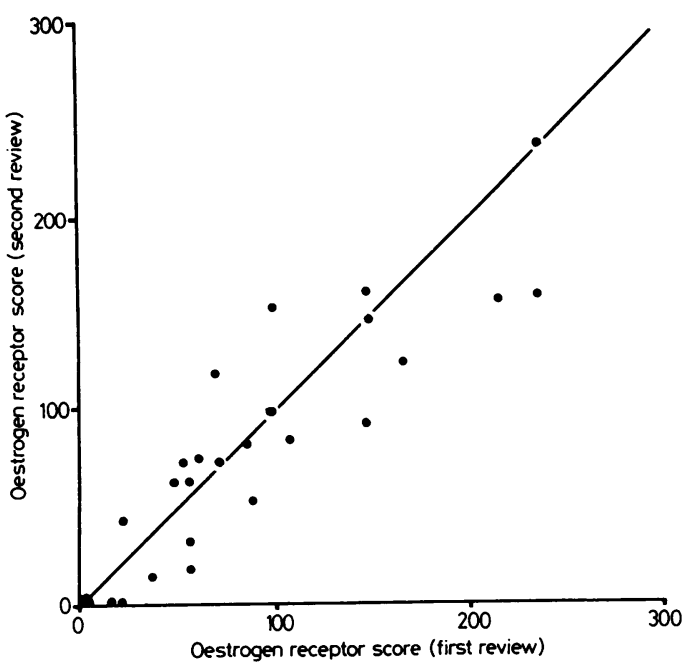

Fig 3 Intraobserver variability of oestrogen receptor score in 26 breast cancer samples, obtained in two separate evaluations by one observer. $(r=0.96, p<0.00001)$.

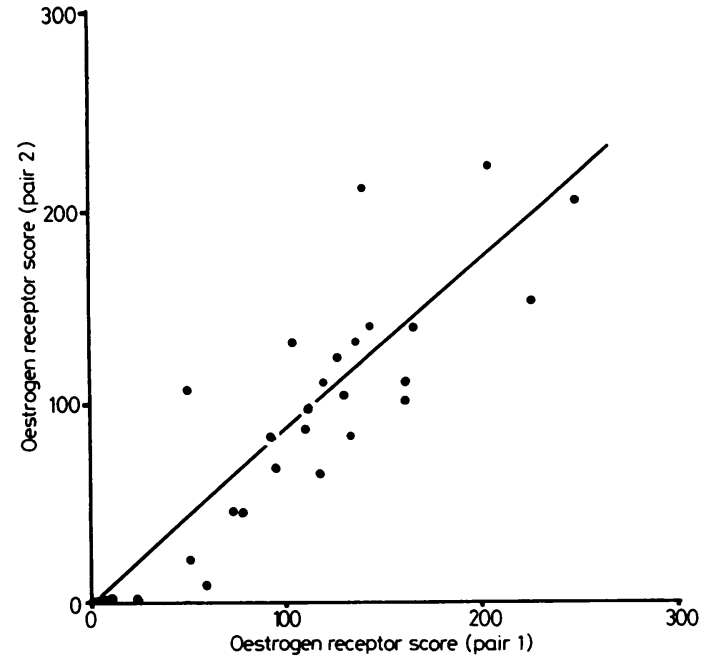

Fig 4 Interobserver variability of oestrogen receptor score in 32 breast cancer samples, obtained independently by two pairs of observers $(r=0.90 ; p<0.00001$; slope $=0.89$; Student's $t$ test $p=0.017)$.

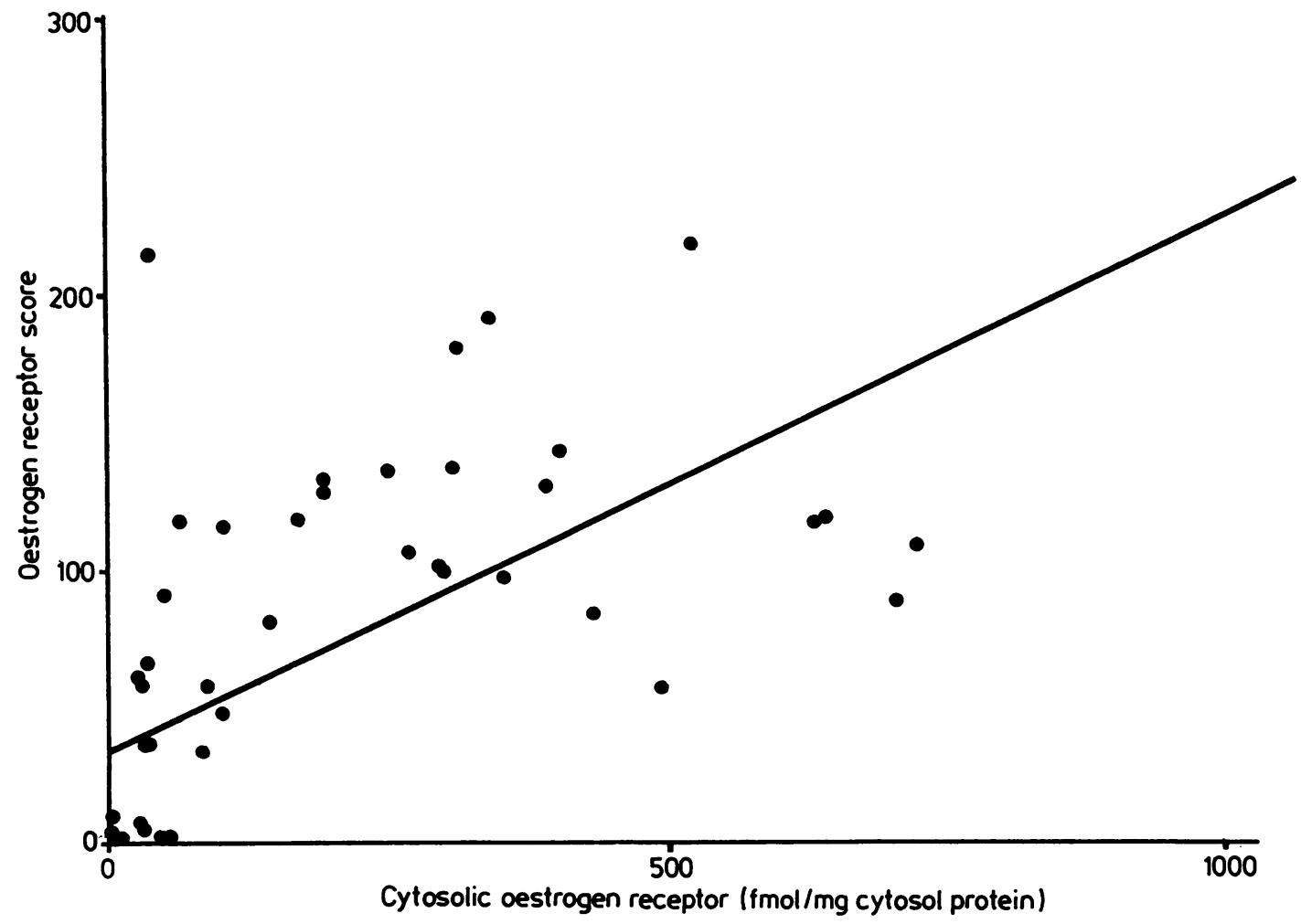

Fig 5 Comparison of immunohistochemical oestrogen receptor score and radiochemical oestrogen receptor assay in cytosol of 50 breast cancer samples. Characteristics of correlation: $r=0.65 ; p<0.00001 ; y=33 \cdot 8+0 \cdot 19 x)$. 
immunocytochemically oestrogen receptor positive tumours. Staining was heterogeneously distributed over the malignant cells in most breast cancer samples. Adjacent epithelial cells of normal breast tissue also often showed nuclear staining. In at least three fields of each section, each field including 100 cells, the nuclear staining was classified into five categories ranging from no (0) to very intense (4) staining and an oestrogen receptor score was obtained as detailed. To facilitate comparison of immunohistochemical and radiochemical results only the total oestrogen receptor scores are presented. It is important to note, however, that significant differences often occurred between the fields.

The intraobserver variability for visual assessment of the oestrogen receptor score was studied. Fig 3 shows a significant linear correlation between both observations $(r=0.96 ; p<0.00001)$.

Interobserver variability in oestrogen receptor scoring by two observer pairs on 26 breast cancer specimens is summarised in fig 4 . The results show a significant linear correlation $(r=0.90 ; p<0.00001)$ but a consistently lower score for one observer pair (slope 0.91, Student's $t$ test $\mathrm{p}<0.017$ ). The interassay
Table 2 Correlation of radiochemical oestrogen receptor assay in cytosol and immunohistochemical oestrogen receptor score for 50 breast cancer samples

\begin{tabular}{ll}
\hline & $\begin{array}{l}\text { Cytosol assay } \\
\text { (fmol oestrogen receptor/ } \\
\text { mg cytosol protein) }\end{array}$ \\
$\geqslant 10$ & $<10$ \\
\hline
\end{tabular}

Immunohistochemical assay

(oestrogen receptor score)

$<35$

$\geqslant 35$

11
0

9*

For cytosol assay a cut off value of $10 \mathrm{fmol}$ oestrogen receptor/mg cytosol protein was used, which corresponds to an oestrogen receptor score of 35 according to equation $y=33.8+0.19 \mathrm{x}$, derived from data in fig 5 .

*The cytosol oestrogen receptor content of these samples varied between 78 and $10 \mathrm{fmol} / \mathrm{mg}$ cytosol protein.

coefficient of variation for the whole immunohistochemical procedure including oestrogen receptor scoring was assessed on homogeneous tissue samples and was found to be $10 \%$.

For the $\mathbf{5 0}$ samples the results of semiquantitative scoring of oestrogen receptor immunoreactivity were

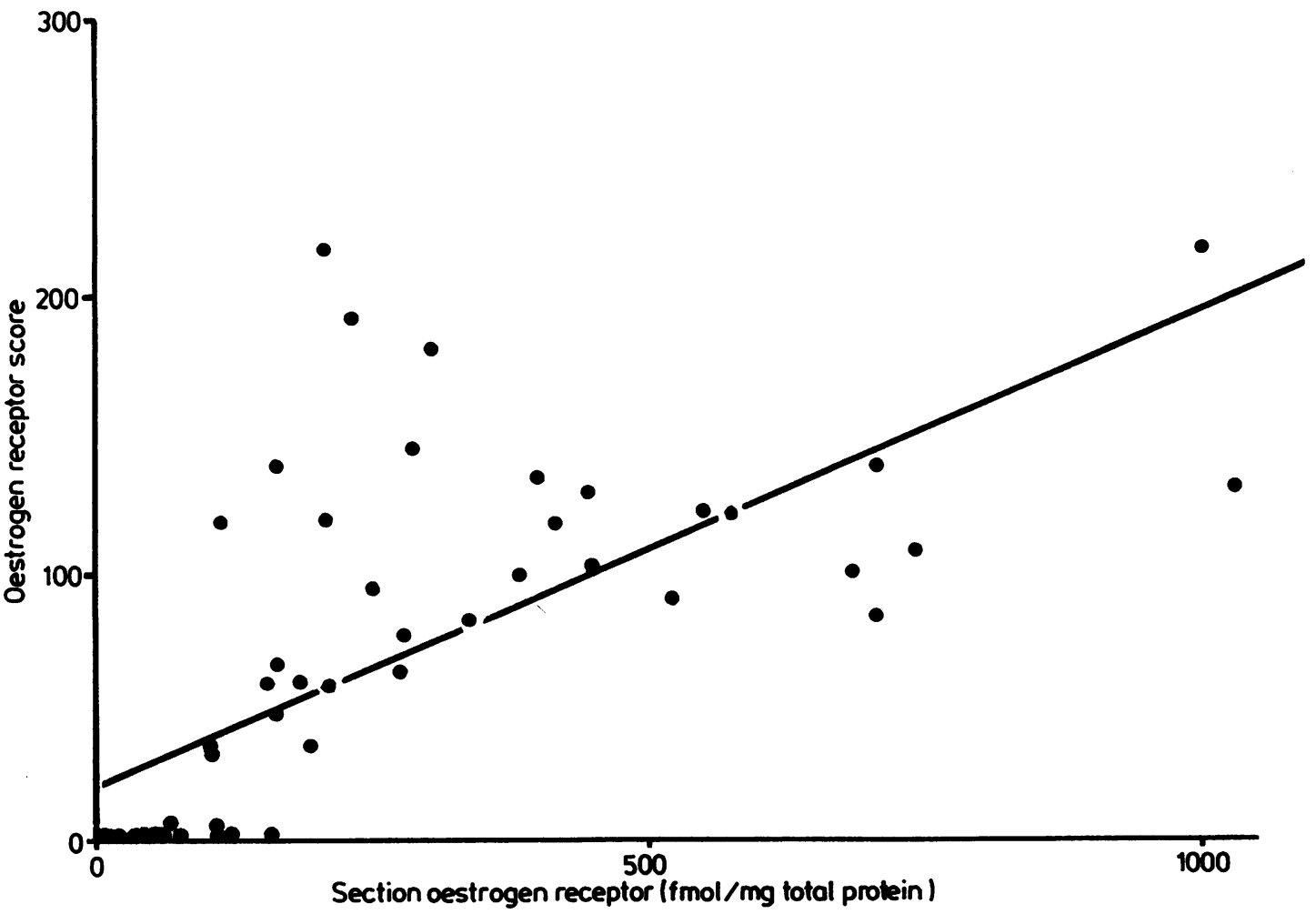

Fig 6 Comparison of immunohistochemical oestrogen receptor score and radiochemical oestrogen receptor assay in sections of 50 breast cancer samples. Characteristics of correlation: $r=0.70 ; p<0.00001 ; y=25 \cdot 2+0.17 x$ ). 
compared with the radiochemical oestrogen receptor binding assays in cytosol as well as in sections. The linear correlation for oestrogen receptor assay in cytosol and the oestrogen receptor score was 0.63 and was highly significant ( $<<0.00001$ ) (fig 5). According to the data from fig 5 , the cut off value of $10 \mathrm{fmol} / \mathrm{mg}$ cytosol protein corresponded to an oestrogen receptor score of 35. Application of these values resulted in the classification of the 50 breast cancers by the cytosol assay and immunohistochemical evaluation (table 2).

Fig 6 shows the linear relation for radiochemical and immunohistochemical quantitation performed on adjacent cryostat sections. The correlation coefficient of 0.70 was highly significant $(p<0.00001)$. The cut off value of $33 \mathrm{fmol} / \mathrm{mg}$ tissue protein corresponded to an oestrogen receptor score of 31 . Classification of the 50 samples according to these assays is shown in table 3.

The results of the linear relations (figs 5 and 6 ) show that the radiochemical determination of oestrogen receptor content in the frozen sections was in better agreement with the semiquantitative immunohistochemical analysis than the oestrogen receptor measurements in the tumour cytosol.

Agreement with regard to receptor status was excellent $(100 \%)$ for breast cancer samples, which were classified as negative with radiochemical assay on cytosol (table 2) and sections (table 3) compared with immunohistochemical oestrogen receptor score. In contrast, $23 \%$ (cytosol) and $18 \%$ (sections) of the radiochemically oestrogen receptor positive tumours had a negative score by immunohistochemistry. The heterogeneous distribution of oestrogen receptors and the strict quantitative correlation of the immunocytochemical and radiochemical determination of oestrogen receptor in adjacent frozen sections taken from different parts of one tumour sample is shown in fig 7 . The plot shows that for each of the four regions of the tumour sample the oestrogen receptor scores were in significant linear correlation with the radiochemical oestrogen receptor content detected in adjacent frozen tumour sections $(r=0.99, p<0.00001)$.

\section{Discussion}

Oestrogen receptors can be specifically determined in frozen sections of normal target tissues with Scatchard analysis using radiolabelled oestradiol. ${ }^{19}$ This report shows that the technique can also be applied for reliable oestrogen receptor assay in comparative studies on breast cancer sections in man.

The binding characteristics are fully compatible with specific oestrogen receptor detection and the reproducibility of the section assay is acceptable. The interassay coefficient of variation was comparable with what has been found for oestrogen receptor determinations in cytosol by several laboratories
Table 3 Correlation of radiochemical oestrogen receptor assay in frozen sections and immunohistochemical oestrogen receptor score of 50 breast cancer samples

Section assay

(fmol oestrogen receptor)

mg tissue protein)

$<33 \quad \geqslant 33$

Immunohistochemical assay

(oestrogen receptor score)

$<31$

$\geqslant 31$

11

0

32

For section assay a cut off value of $33 \mathrm{fmol}$ oestrogen receptor/mg tissue protein was used, which corresponds to an oestrogen receptor score of 31 according to equation $y=25.2+0.17 \mathrm{x}$, derived from data in fig 6.

*The section oestrogen receptor content of these samples varied between 65 and $110 \mathrm{fmol} / \mathrm{mg}$ tissue protein. These samples $(\mathrm{n}=7)$ are all included in the nine samples with more than $10 \mathrm{fmol} / \mathrm{mg}$ cytosol protein (table 2 ).

participating in steroid receptor assay quality control programmes. ${ }^{27}{ }^{30} \mathrm{~A}$ highly significant linear relation was found between the results of radiochemical assay on sections and cytosol prepared from adjacent tissue blocks.

The agreement of receptor status classification of the specimen between both radiochemical methods

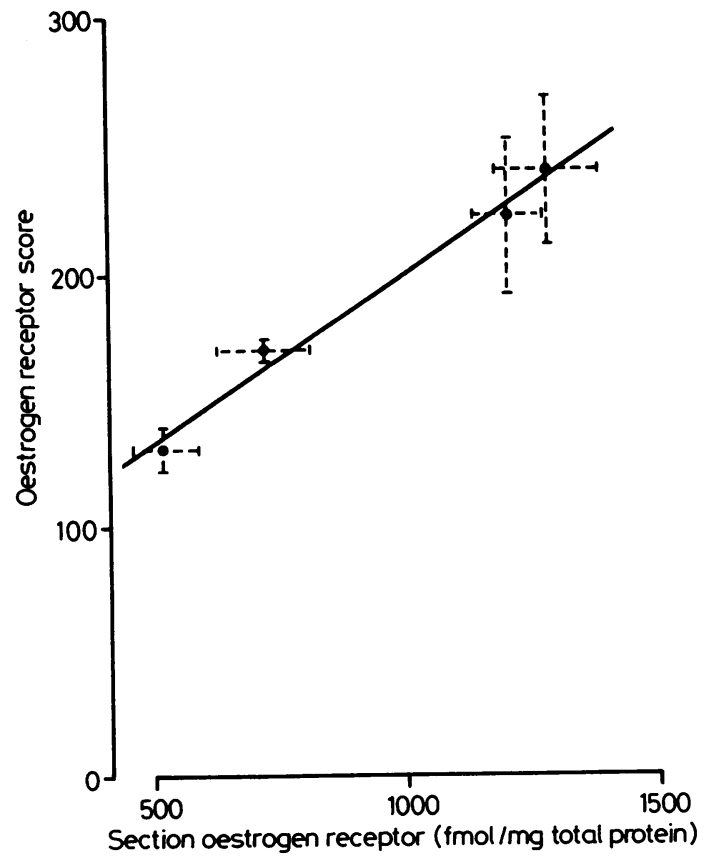

Fig 7 Correlation between immunohistochemical oestrogen receptor score and radiochemical oestrogen receptor assay in sections for multiple samples obtained from one breast cancer biopsy specimen ( $r=0.993 ; p<0.00001)$. 
was excellent (97.5\%) when a cut off value of $10 \mathrm{fmol}$ oestrogen receptor/mg cytosol protein was used. Cases negative by radioligand assay but positive by immunocytochemical assay may be due to heterogeneity within the tumour samples: this has been repeatedly shown in breast cancer. ${ }^{7-14}$ Cases positive by radioligand assay but negative by immunocytochemical assay can occur when tumour samples contain appreciable amounts of oestrogen receptor positive non-neoplastic cells, which are not taken into account in the immunocytochemical assay.

As in the previous study ${ }^{19}$ part of the oestrogen receptor content was found to elute from the unfixed breast cancer sections into the overlaying buffer during incubation, while more than $90 \%$ of the rest remained bound to the sections, even after extensive washing. In contrast to the results on normal tissue, in this breast cancer series the relative amount of soluble receptors was highly variable.

We noticed that the mean dissociation constant for soluble receptors was lower than that for sectionbound oestrogen receptor. This slight but significant difference in binding affinity suggests that there are two receptor forms or populations with different protein conformation. These conformational differences may be induced by receptor binding to cellular structures. Alternatively, the state of phosphorylation might be important. On the other hand, as all cells in a $6 \mu \mathrm{m}$ section are opened up, part of the oestrogen receptor that is assayed in the overlay buffer might be bound to cell fragments which are lost from the unfixed section during incubation. Although the mean dissociation constants for cytosol and soluble oestrogen receptor did not differ significantly, we cannot assume that they were directly comparable; no significant relation among receptor contents was found in the 50 breast cancer samples.

Although both radiochemical assays could not detect the oestrogen receptor content of individual cancer cells, the assay on sections has several advantages over that of cytosol. Firstly, parallel or directly adjacent sections can be used for routine histological verification of the sample for histodiagnostic purposes and for histochemical and immunohistochemical studies. Secondly, less tissue is required for Scatchard analysis (about 50-80 mg of fresh tissue compared with at least $200 \mathrm{mg}$ for cytosol assay). This could be important, in view of the tendency towards a decreasing mean size of primary breast cancer samples due to detection at an earlier stage of the disease. The difference may be due to loss of receptor binding function during cytosol preparation, such as heat denaturation during homogenisation, protease activity, and removal of the nuclear fraction.

On the other hand, better preservation of oestrogen receptor in section assay can be explained by very rapid drying of the frozen section, high stability of receptor preparations in a dry state, ${ }^{1931}{ }^{32}$ and minimal delay in incubating the tissue with receptor ligand which stabilises the receptor binding function.

The characteristics of oestrogen receptor immunoreactivity, most notably the predominant nuclear localisation and the pronounced heterogeneous cellular distribution, agree with the findings of other studies using the same or similar monoclonal antibodies. ${ }^{20-25}$ For the semiquantitative evaluation of immunostaining, several approaches have been described, such as determination of the percentage of positive cells, ${ }^{242533} 34$ classification in varying numbers of categories, ${ }^{22} 242534$ and various mathematical analyses. ${ }^{2324} \mathrm{We}$ chose a slight modification of the method of McCarty et al. ${ }^{22}$ Our intra- and interobserver variability studies showed that semiquantitative scoring of oestrogen receptor immunoreactivity was highly reproducible for one observer, but could result in significantly different oestrogen receptor scores for different observers. This effect will be more pronounced when no standard preparations for reference are used. In addition to observer and calculation variations, differences in experimental conditions may also produce significant quantitative discrepancies. Therefore, before semiquantitative immunohistochemical oestrogen receptor analysis is applied for clinical purposes, development of quality control programmes for this technique, similar to those which are currently used for radiochemical steroid receptor assays, ${ }^{2730}$ should be implemented.

Positive correlations between oestrogen receptor immunohistochemistry and cytosol assay have been reported. ${ }^{22-25}{ }^{33}$ Our finding that oestrogen receptor scores correlated better with radiochemical oestrogen receptor assay on parallel sections than with cytosol underlines the importance of cellular and sample heterogeneity as a cause of variation in oestrogen receptor assay evaluation. A high correlation between anti-oestrogen receptor immunohistochemistry and enzyme immunoassay and a radioligand binding assay on adjacent cryostat sections was also found by Giri $e t$ $a l,{ }^{25}$ although a different technical approach for the radiochemical assay was taken. Individual cases, however, may show discrepancies between radioligand assay and immunocytochemical results on adjacent cryostat sections.

Cases negative by radioligand binding assay but positive by immunohistochemical assay may be due to methodological errors in the radioligand assay or to dilution of cytosol with oestrogen receptor negative material in samples with a low oestrogen receptor positive cell content. Cases negative by immunohistochemical assay but positive by radioligand assay may be due to the methodological difference between detecting a molecule through antigen-antibody bind- 
ing and receptor-ligand binding, although the monoclonal anti-oestrogen receptor antibody recognised an epitope that is distinct from the oestradiol binding site of the receptor. Furthermore, admixture of oestrogen receptor positive, non-neoplastic cells, which are not taken into account in the immunohistochemical oestrogen receptor score, may be responsible. Similar discrepancies between immunohistochemical and radioligand binding assay have been reported. ${ }^{3536}$ Whether breast cancers with negative oestrogen receptor scores belong to the group of non-responders to endocrine treatment in the cytosol oestrogen receptor positive group of breast cancer patients, as has been reported earlier, ${ }^{36}$ has to be verified. Final validation of semiquantitative immunohistochemical oestrogen receptor assay for clinical use awaits assessment of its ability to predict the response to hormonal treatment and the prognosis.

Semiquantitative analysis, resulting in a single number score, does not take into account the possibility that heterogeneity may contain important biological information. We feel that the distribution pattern of the staining intensity of the tumour cells should be separately analysed in relation to clinical data. In this respect, the ability to show the presence of oestrogen receptor in paraffin sections is important. Some attempts have been reported ${ }^{37-40}$ but as yet no validated techniques for routinely fixed malignant tissue have been described.

In conclusion, we have shown that cryostat sections of breast cancer can be used for radiochemical oestrogen receptor assay, and that the radiochemical section assay is a reliable and reproducible technique, which offers advantages over the use of cytosol. The semiquantitative immunohistochemical oestrogen receptor score correlates better with radiochemical assay on sections compared with cytosol. The results indicate that oestrogen receptors may be reliably quantitated by semiquantitative evaluation of specific immunostaining in cryostat sections of human breast cancer, but only if this technique is adequately standardised.

We thank Mr C de Waal van Anckeveen for expert technical help with the oestrogen receptor cytosol assay and Marianne Rikers for secretarial assistance. We gratefully acknowledge the financial support of the Netherlands Cancer Foundation KWF.

\section{References}

1 McGuire WL. An update on estrogen and progesterone receptors in prognosis for primary and advanced breast cancer. In: Iacobelli S, ed. Hormones and cancer. New York: Raven Press, 1980:337-43.

2 DeSombre ER. Breast cancer: hormone receptors, prognosis and therapy. Clin Oncol 1982;1:191-213.

3 Allegra JC, Lippman ME, Thomson EB, et al. Estrogen receptor studies: an important variable in predicting response to endocrine therapy in metastatic breast cancer. Eur $J$ Cancer 1980;16:323-31.

4 Greene GL, Sobel NB, King WJ, Jensen EV. Immunochemical studies of estrogen receptors. J Steroid Biochem 1984;20:51-6.

5 Leclercq G, Bojar H, Goussard J, et al. Abbott monoclonal enzyme immunoassay measurement of estrogen receptors in human breast cancer: a European multicenter study. Cancer Res 1986;46:4233S-6S.

6 Thorpe SM, Lykkesfeldt AE, Vinterby A, Lonsdorfer M. Quantitative immunological detection of estrogen receptors in nuclear pellets from human breast cancer biopsies. Cancer Res 1986;46:4251S-5S.

7 Osborne CK. Heterogeneity in hormone receptor status in primary and metastatic breast cancer. Semin Oncol 1985;12:317-26.

8 Silverswärd G, Skoog L, Humla S, Gustafsson SA, Nordenskjöld D. Intratumoral variation of cytoplasmic and nuclear receptor concentrations in human mammary carcinoma. Eur $J$ Cancer 1980;16:59-65.

9 Hull DF, Clark GM, Osborne CK, Chamness JC, Knight WA, McGuire WL. Multiple estrogen receptor assays in human breast cancer. Cancer Res 1983;43:413-6.

10 Davis BW, Zava DT, Locher GW, Goldhirsch A, Hartmann WH. Receptor heterogeneity of human breast cancer as measured by multiple intratumoral assays of estrogen and progesterone receptor. Eur J Cancer Clin Oncol 1984;20:375-82.

11 Van Netten JP, Algard FTh, Coy P, et al. Heterogeneous estrogen receptor levels detected via multiple microsamples from individual breast cancers. Cancer 1985;56:2019-24.

12 Geyer H, Eberl M, Hornberger B. Influence of tissue heterogeneity on the determination of steroid receptors in breast cancer. $J$ Cancer Res Clin Oncol 1985;110:141-4.

13 Norgren A, Fernö M, Borg Å. Observations on wet weight, protein and DNA as reference for steroid receptors in malignant mammary tumors. Anticancer Res 1986;6:59-64.

14 Howanitz PJ, Howanitz JH, Skrodzki CA, Woloszyn T. Protein method influences on calculation of tissue receptor concentration. Am J Clin Pathol 1986;85:37-42.

15 Underwood JCE, Dangerfield VJM, Parsons MA. Oestrogen receptor assay of cryostat sections of human breast carcinomas with simultaneous quantitative histology. $J$ Clin Pathol 1983;36:399-405.

16 Underwood JCE. Oestrogen receptors in human breast cancer: review of histopathological correlations and critique of histochemical methods. Diagn Histopathol 1983;3:1-22.

17 Giri DD, Lonsdale RN, Dangerfield VJM, Harris SC, Parsons MA, Underwood JCE. Clinicopathological significance of intratumoural variations in elastosis grades and the oestrogen receptor status of human breast carcinomas. $J$ Pathol 1987;151:297-303.

18 De Goeij AFPM, Bosman FT, Berns EMJJ. Determination of steroid hormone-dependency of tumors utilizing tissue sections. Survey of histochemical techniques and their application in surgical pathology. J Pathol 1986;149:163-72.

19 De Goeij AFPM, Volleberg MPW, Hondius GG, Bosman FT. Radiochemical determination of estrogen receptors in cryostat sections of target tissues. J Steroid Biochem 1984;21:127-34.

20 King WJ, Greene GL. Monolonal antibodies localize oestrogen receptor in the nuclei of target cells. Nature 1984;307:745-7.

21 Press MF, Greene GL. An immunocytochemical method for demonstrating estrogen receptor in human uterus using monoclonal antibodies to human estrophilin. Lab Invest 1984;50:480-6.

22 McCarty KS, Miller LS, Cox EB, Konrath J, McCarty KS. Estrogen receptor analyses: correlation of biochemical and immunohistochemical methods using monoclonal antireceptor antibodies. Arch Pathol Lab Med 1985;109:716-21.

23 Hawkins RA, Sangster K, Krajewski A. Histochemical detection of oestrogen receptors in breast carcinoma-a succesful tech- 
nique. Br J Cancer 1986;53:407-10.

24 DeSombre ER, Thorpe SM, Rose C, et al. Prognostic usefulness of estrogen receptor immunocytochemical assays for human breast cancer. Cancer Res 1986;46:4256S-64S.

25 Giri DD, Dangerfield VJM, Lonsdale R, Rogers K, Underwood JCE. Immunohistology of oestrogen receptor and D5 antigen in breast cancer: correlation with oestrogen receptor content of adjacent cryostat sections assayed by radioligand binding and enzyme immunoassay. J Clin Pathol 1987;40:734-40.

26 EORTC Breast Cancer Cooperative Group. Revision of the standards for assessment of hormone receptors in human breast cancer. Eur J Cancer 1980;16:1513-5.

27 Koenders A, Thorpe SM. Standardization of steroid receptors assays in human breast cancer. 4. Long-term within laboratory and between laboratory variation of estrogen and progesterone receptor assays. Eur J Cancer Clin Oncol 1986;22:945-52.

28 Bradford MM. A rapid and sensitive method for the quantitation of microgram quantities of protein utilizing the principle of protein-dye binding. Anal Biochem 1976;72:248-54.

29 Stefanini M, De Martini C, Zamboni L. Fixation of ejaculated spermatozoa for electron microscopy. Nature 1967;216:173.

30 Jordan VC, Zava DT, Eppenburger U, et al. Reliability of steroid hormone receptor assays - an international study. Eur J Cancer Clin Oncol 1983;19:357-63.

31 Thorpe SM, Koenders A. Standardization of steroid receptor assays in human breast cancer. 3. Selection of reference material for intralaboratory and inter-laboratory quality control. Eur $J$ Cancer Clin Oncol 1986;22:939-44.

32 Benraad Th, Koenders A. Estradiol receptor activity in lyophilized calf uterus and human breast tumor tissue. Cancer 1980; 46:2762-4.

33 Heubner A, Beck T, Grill H-J, Pollow K. Comparison of immunocytochemical estrogen receptor assay, estrogen receptor enzyme immunoassay, and radioligand-labeled estrogen receptor assay in human breast cancer and uterine tissue. Cancer Res 1986;46:4291S-5S.

34 King WJ, DeSombre ER, Jensen EV, Greene GL. Comparison of immunocytochemical and steroid-binding assays for estrogen receptor in human breast tumors. Cancer Res 1985;45:293-304.

35 Jonat W, Maass H, Stegner HE. Immunohistochemical measurement of oestrogen receptors in breast cancer tissue samples. Cancer Res 1986;46:4296S-8S.

36 McClelland RA, Berger U, Miller LS, Powles TJ, Jensen EV, Coombes RC. Immunocytochemical assay for estrogen receptor: relation to outcome of therapy in patients with advanced breast cancer. Cancer Res 1986;46:4241S-3S.

37 Shimada A, Kimura S, Abe K, et al. Immunocytochemical staining of estrogen receptor in paraffin sections of human breast cancer by use of monoclonal antibody: comparison with that in frozen sections. Proc Natl Acad Sci USA 1985;82:4803-7.

38 Andersen J, Orntoft J, Poulsen SH. Semiquantitative oestrogen receptor assay in formalin-fixed paraffin sections of human breast cancer tissue using monoclonal antibodies. $\mathrm{Br} \mathrm{J}$ Cancer 1986;53:691-4.

39 Shintaku IP, Said JW. Detection of estrogen receptors with monoclonal antibodies in routinely processed formalin-fixed paraffin sections of breast carcinoma: use of Dnase pretreament to enhance sensitivity of the reaction. Am J Clin Pathol 1987;87:161-7.

40 Teasdale J, Jackson P, Holgate CS, Cowen PN. Identification of oestrogen receptors in cells of paraffin-processed breast cancers by IGSS. Histochemistry 1987;87:185-7.

Requests for reprints to: Dr A F P M de Goeij, Department of Pathology, University of Limburg, POB 616, 6200 MD Maastricht, The Netherlands. 